\title{
Effect of Activity Tracker \& Application Use on Adherence, Metabolic Syndrome Factor and Body Composition in Middle and Senior-Aged
}

\author{
Dong Jin Kim¹, Min Su Kim¹, Na Young Park', Su Geol Lee', Yeon Kyung Lee ${ }^{{ }^{*}}$ \\ ${ }^{1}$ Korea Health Promotion Institute, Seoul, Korea
}

Received: December 22, 2017

Accepted: March 13, 2018

Published online: April 30, 2018

Keywords:

Activity tracker

Application

Adherence

Metabolic syndrome factor

Public health center
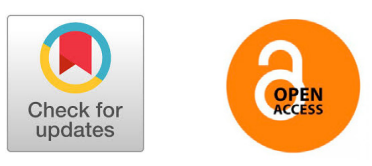

\begin{abstract}
PURPOSE The purpose of this study was to investigate effects of activity tracker \& application use on adherence, metabolic syndrome factor and body composition of middle and senior-aged.

METHODS The subjects of this study were 1,196 middle and senior-aged man and women with health hazard factor. All of subjects divided to two groups, activity tracker $\&$ application use group 990 ( $m a n=492$, women=498) was participating in 24 weeks, and control group 206 ( $m a n=71$, women=135) was not in that program. They performed physical activity utilizing activity tracker \& application for 24 weeks. The following items were measured before, middle and after the program : physical activity adherence, metabolic syndrome factor and body composition.

RESULTS Results of this study showed that physical activity adherence appeared nothing in drop-rate of male(9.35\%) and female(8.63\%) : So adherence were male(90.65\%) and female(91.37\%). And changes of metabolic syndrome factor variables were significantly improved in total cholesterol, triglyceride, systolic blood pressure, and glucose in activity tracker \& application use group and control group after 24 weeks. Also, body composition were showed significantly different in BMI, weight, waist.

CONCLUSIONS Activity tracker \& application use accompanied regular physical activity were effective in middle and senior-aged health promotion. This results can be utilized not only in new health promotion program of public health center but also in a local resident health management strategies.
\end{abstract}

(๑) The Asian Society of Kinesiology and the Korean Academy of Kinesiology

\section{서론}

경제수준의 향상이 환경요인과 생활습관 등의 변화를 가져옴에 따라 만성질병의 증가를 초래하였다. 2012년 경 제협력개발기구(OECD) 보고서에 의하면, 세계인구의 $60 \%$ 가 만성질병으로 사망하고 있고(OECD, 2012), 대한민 국의 만 30 세 이상 성인 만성질병 유병율은 고혈압 $30.4 \%$,

*Correspondence: Yeon kyung Lee, Korea Health Promotion Institute, Namsan Square B/D, 173 Toegye-ro, Jung-gu, Seoul 04554, Republic of Korea.

E-mail: carine90@khealth.or.kr
당뇨병 $11.9 \%$, 고콜레스테롤혈증 $15.9 \%$, 고중성지방혈증 $17.6 \%$ 라고 발표하였다(Ministry of health and welfare, 2013).

그리고 건강보험 진료비는 2015년 57조 9,546억원으로 전년대비 $6.5 \%$ 증가하였으며, 그 중 만성질병 건강보험 진 료비는 21 조 2,994 억원으로 전체 진료비의 $36.8 \%$ 차지하 고 있다(Health insurance review \& assessment service, 2016). 만성질병에 관한 발생 원인과 기전이 정확하게 규명 되지는 않았지만, 보편적으로 신체활동의 부족과 과도 한 식이섭취가 주요한 원인이다(Kannel et al., 1996; Poskitt, 2005). 세계보건기구(WHO)에서는 이미 2011년부터 만성 질병(심장질환, 뇌졸중, 당뇨병, 이상지질혈증 등)으로 인 
한 조기사망의 $80 \%$ 정도는 금연, 규칙적인 운동, 건강한 식 생활습관 등의 일상 생활습관 개선을 통하여 예방이 가 능하다고 하였다(WHO, 2011). 규칙적인 신체활동은 비 만을 예방하고 심혈관질환 발병율과 사망 위험을 줄이며 주당 $1,000 \mathrm{kcal}$ 가량의 신체활동 혹은 약 $1 \mathrm{MET}$ 정도의 심 폐체력 증가는 인간의 사망률을 $20 \%$ 나 감소시킨다(Myers et al., 2003)고 하였고, 활동량 증가에 따른 체중감소는 고혈압, 당뇨병 및 고지혈증과 같은 만성질환을 예방하 고 개선하는데 아주 효과적이라고 보고하였다(Orzano \& Scott, 2004). 이러한 신체활동의 긍정적인 연구결과에도 불구하고, 여전히 신체활동 실천율은 저조하고 과체중 및 비만과 대사증후군 유병률은 지속적인 증가추세를 보이 고 있다. $\operatorname{Han}(2016)$ 은 대한민국 전국 254개 시/군/구 약 22 만 명의 성인 대상으로 조사한 '2014년 지역사회 건강조 사' 에서 하루 30 분 이상 걷기를 주 5 일 이상 실천하는 사 람은 2008년 50.6\%에서 2012년 40.8\%, 2014년에 는 37.5\%로 감소 추세이고, 국민의 생활체육참여 및 국민체력 실태 조사에서도 국민의 $35.9 \%$ 만이 규칙적인 운동을 실천하고 있으며 젊은 세대의 경우에는 '운동을 전혀 하지 않는' 여성의 비율이 20 대는 $67.3 \%, 30$ 대는 $63.1 \%$ 에 이르고, 남 성의 경우에도 20 대 $50.0 \%, 30$ 대 $48.4 \%$ 로 매우 높게 나타 나 “신체활동 실천율 증가” 에 대한 부분이 중요한 문제 라고 언급하였다.

선행연구를 살펴보면 신체활동을 촉진시키기 위한 많 은 연구들이 수행되었는데, Carron et al.(2003)은 환경 촉 진물, 운동시설 접근 용이성에 대한 지각, 그리고 운동시 설에 대한 실제적 접근 가능성 등의 물리 「환경적 요인이 신체활동 촉진에 유의한 영향을 미친다고 하였다. 또한 자가 점검(self-monitoring), 행동적 목표설정, 신체활동 증 가를 위한 자극 및 보상과 같은 변인들과 밀접한 관계가 있다고 하였다(Vicki et al., 2011). 최근에는 동작가속도계 (accelerometer)와 같은 기기를 활용하여 거리와 속도측 정 및 그에 따른 에너지소비량과 활동정도를 산출하여 신체활동에 대한 질적, 양적인 정보를 제공하고 있다. 이 는 동작가속도계가 걸음수를 측정하는 도구뿐만 아니라, 자가 모니터링(self-monitoring) 기능을 통해 신체활동을 촉진시키는 동기유발 도구의 의미가 있다(Gwon \& Rhee, 20104).

현 대사회는 네트워크를 중심으로 하는 컴퓨터 매개 통 신(Computer Mediated Communication) 플랫폼에 의해 사 회문화가 형성되어 있다. 특히 시간과 공간의 제약을 받
지 않으면서 다양한 형태로 데이터를 입「출력할 수 있는 네트워크는 언제/어디서든지, 어느 누구와도 의사소통을 할 수 있다(Kim et al, 2011). 이러한 플랫폼의 장점을 활용 하여 동작가속도계 외에 블루투스 기능이 탑재된 활동량 계(activity tracker)와 스마트 기반 앱(APP)을 활용하여 신 체활동 걸음수, 이동거리, 활동소비량, 그리고 활동강도 등을 관리하는 것은 매우 효과적일 수 있다. 최근 지역 보 건소에서는 국가건강검진 결과를 활용한 건강관리 사업 을 오프라인으로 실시하고 있으나, 대면상담을 위한 방문 의 번거로움 등으로 참여희망자 중 약 $7 \%$ 만 서비스를 이 용하고 있는 실정이다(Khealth, 2016).

한편, 방송통신위원회에서는 2011년 11월 대한민국의 스마트폰 사용자수는 20,000천명을 넘어섰고 2016년 12 월 기준 46,000천명이라고 발표하였다(Ministry of Science, ICT and Future Planning, 2017). 사실 활동량계와 스마트폰 은 항상 몸에 지니고 다니는 특성으로 인하여 자신의 신 체활동 정도를 확인하는 장치로서 매우 유용한데, Jung et al.(2016)의 아동/청소년의 활동량계 사용에 대한 선호도 조사, 초등학생이 모바일 웹을 활용한 자가건강관리의 효 과(Lee et al, 2015) 및 스마트 폰을 사용하여 대학생 신체 활동량 증가(Kim, 2012) 등을 보고한 선행연구에서 확인 할 수 있다. 그리고 '2016피트니스 트렌드 보고서' 에 서 웨어러블 테크놀로지(Wearable Technology)가 1위를 차 지하였는데, 이러한 결과는 활동량계와 스마트 폰 앱으로 자신의 신체활동을 모니터링하고 개인에 맞는 운동프로 그램을 설정할 수 있도록 도와주는 기술이 큰 인기를 끌 고 있다는 것을 증명하고 있다(Thompson, 2014).

앞에서도 언급했듯이 대한민국 국민의 신체활동 실천 율은 점차적으로 감소하고 있으며, 과체중 및 비만과 대 사증후군 유병률은 지속적인 증가추세를 보이고 있다. 이 처럼 건강위험 예방차원에서 신체활동 참여를 촉진시키 기 위한 효과적인 중재(intervention)방안이 필요한 시점 에 활동량계와 스마트 기반 앱 활용은 바쁜 일상생활 속 에서 자가 건강관리가 어려운 30 50대의 중장년층에 게 매우 중요한 중재방안이 될 수 있다. 또한 지역사회 보건 소의 새로운 건강관리 방안과 전략으로 확대하는데도 의 미가 있을 것이다.

따라서 본 연구는 시간과 공간의 제약이 없는 활동량 계와 스마트 기반 앱을 활용하였을 때, 신체활동 지속도 와 만성질환과 관련이 있는 대사증후군 위험요인 및 신체 조성에 어떠한 영향을 미치는지를 조사하고 나아가 이미 
검증된 보건소 오프라인 건강관리서비스와의 비열등성 비교를 확인해 보는데 그 목적이 있다.

\section{연구 방법}

\section{연구대상}

연구대상은 전국 소재 10 개 보건소 협조 하에 대상증 후군 위험요인이 1 개 이상인 성인 1,000 명(남자 494 명, 여 자 506명)으로 스마트폰을 소지하고 있는 사람들로 제한 하였다. 연구에 참여하기 전 연구목적과 내용에 관하여 충분히 설명하였고, LS Band 2-230 활동량계(Healthmax, Korea) 제공과 스마트폰에 앱을 설치한 후, 사용방법에 대한 교육을 실시하였다. 그러나 총 인원 중 10 명(남성 2 명, 여성 8 명)은 12 주 후 중간검사 기간에 검사 미참여로 인하여 연구대상에서 제외되어 총 대상자는 990명(남성 492명, 여성 498명)으로 하였다. 그리고 기존 보건소 건강 관리사업과의 효과를 비교 평가를 위하여 유사한 조건의 대조군을 선정하였다. 대조군은 10 개 보건소 중 효과가 검증된 내소형 건강원스톱서비스 등의 건강관리서비스 (Kim \& Lee, 2012)를 제공받고 있는 3개소 276명으로 선정 하였으며 사전검사, 12 주 후 중간검사 및 최종 24 주 후까 지 검사를 받은 206(남성 71명, 여성 135명)명을 최종 대상 자로 선정하였다. 연구대상자의 신체적 특성은 <Table 1> 과 같다.

\section{실험설계 및 절차}

본 연구의 목적을 달성하기 위하여 참여대상자는 사전 에 혈액검사와 신체검사 및 허리둘레를 측정하고 12 주 후 에 사전검사와 동일한 항목을 동일 시간대에 중간측정하 며 마지막으로 24 주 후에 중간검사와 동일하게 재측정하 여 총 3 회의 측정을 진행하였다. 실험설계 및 절차는 <Figure $1>$ 과 같다.

\section{허리둘레 및 혈압검사}

대상자의 허리둘레는 2010년에 수행된 제6차 한국인 인체치수 조사사업(Size Korea)에서 제시한 방법을 사용 하여 대상자 배꼽을 지나는 높이에서 측정하였다. 그리 고 혈압은 BPBIO320S 자동혈압기(Inbody, Korea)를 사용 하여 수축기혈압(systolic pressure, $\mathrm{mmHg}$ )과 이완기혈압 (diastolic pressure, $\mathrm{mmHg}$ )을 측정하였다.

\begin{tabular}{lcccc}
\hline \multicolumn{5}{c}{ Table 1. Physical characteristic of subjects $(\mathrm{M} \pm \mathrm{SD})$} \\
\hline Group & $\begin{array}{c}\text { Height } \\
(\mathrm{cm})\end{array}$ & Weight $(\mathbf{k g})$ & $\begin{array}{c}\text { Age } \\
(\mathbf{y r})\end{array}$ & $\begin{array}{c}\mathrm{BMI} \\
\left(\mathrm{kg} / \mathrm{m}^{2}\right)\end{array}$ \\
\hline $\begin{array}{c}\mathrm{G} 1 \\
(\mathrm{n}=990)\end{array}$ & $165.6 \pm 8.5$ & $70.9 \pm 12.8$ & $44.7 \pm 8.2$ & $25.7 \pm 3.3$ \\
\hline $\begin{array}{c}\mathrm{G} 2 \\
(\mathrm{n}=206)\end{array}$ & $163.3 \pm 8.4$ & $67.4 \pm 12.4$ & $44.7 \pm 8.9$ & $25.2 \pm 3.5$ \\
\hline $\begin{array}{l}\text { G1: Experimental group } \\
\text { G2: Control group }\end{array}$ & & & \\
\hline
\end{tabular}

\section{혈액검사}

혈액검사는 현장검사 장비인 Samsung LABGEO PT10(Samsung Electronics, Suwon, Korea)을 사용하여 혈장 및 혈청뿐만 아니라, 전혈 검체로 임상화학분석검사를 실시하였다. Jung et al.(2013)에 의하면 Samsung LABGEO $\mathrm{PT} 10$ 은 임상화학 현장검사 장비로 수행평가 검증이 완 료된 신뢰할 수 있는 장비이다. 대상자의 손가락에서 검 체 $70 \mathrm{uL}$ 을 10 분간 상온화 된 카트리지에 주입하고 검사장 비 도어에 삽입하여 7분 후 총 콜레스테롤(TC), 중성지방 (TG), 공복혈당, 고밀도지단백-콜레스테롤(HDL-C)을 확 인하였다.

\section{신체조성 검사}

대상자의 신체계측을 측정하기 위하여 생체전기 임피

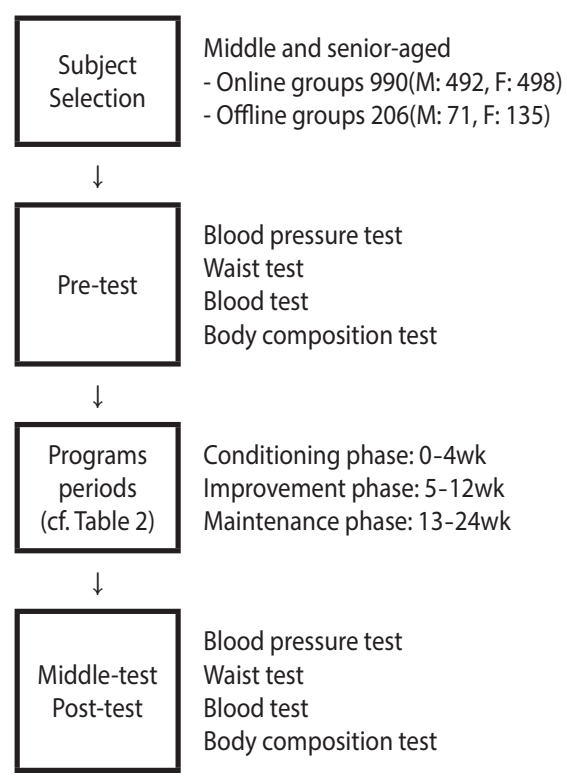

Figure 1. Experimental design 
던스 검사(bioeletrical impedance analysis) 장비(Inbody 370, Inbody, Korea)을 이용하였다. 검사방법은 대상자가 양발 을 기기 받침대 발바닥 모양에 맞춰 올라 선 후 양손으로 손잡이를 잡으면 체중, 근육량, 체지방량 등이 자동으로 측정되도록 하였다. 검사기는 인체에 무해한 고주파수 $(500 \sim 800 \mathrm{KHz})$ 를 전도시켜 지방조직과 비지방조직의 전 기저항 차이를 이용하여 지방량이나 근육량, 수분량 등을 추적할 수 있는 장비이다.

\section{스마트 기반 모바일 헬스케어 앱}

본 연구에서 사용된 스마트 기반 모바일 헬스케어 앱 은 Kim et al.(2010)이 개발한 “웹 기반 개인운동처방 시 스템” 의 출력정보를 일반인들이 손쉽게 확인할 수 있도 록 모바일 환경으로 재구성하였다. 그리고 개인의 신체 활동량 정보는 활동량계에서 앱으로 자동 연동되어 스마 트폰에서 활동량 정보를 실시간으로 확인할 수 있도록 하 였고, 그 외 운동일기 형식으로 별도 수행한 운동내역(유 산소 or 저항성운동)을 입력하여 활동량 누적정보를 통계 데이터로 제공하였다. 또한 평상시 식사 때마다 섭취하 는 식단을 사진 혹은 텍스트 형식으로 앱에 입력하고 각 음식에 대한 양을 단위로 입력할 수 있도록 구성하였다.

한편, 프로그램 언어는 JSP와 Oracle 및 JAVA기반으로 설계하여 '모바일 앱 기반서비스' 로 제공하였다. 그리 고 자가 건강관리 및 코칭서비스를 위해 스마트 기반 앱 과 연동되는 '관리자 웹 시스템' 을 추가 구성하였으며 $\mathrm{DB}$ 파일은 사용자정보, 상담정보, 건강콘텐츠정보, 서비 스정보, 신체계측정보 등 5 개 분야의 180 개 테이블로, 마 지막 푸시(push), 건강포인트, 랭킹 등을 자동화 모듈서비 스로 구성하였다.

\section{신체활동 목표처방 및 상담시스템}

신체활동 목표처방은 미국스포츠의학회(american college of sports medicine)에서 제시한 일일 신체활동 소모 칼로리 기준에 의해(ACSM, 2006) 주간 소비칼로리를 제 시하였다. 그리고 매우 우수한 체력일지라도 운동강도 는 최대심박수의 70\%는 넘지 않도록 하여, Ainsworth et al.(2000)이 발표한 "인체의 에너지 소비량 분류에 따른 신체활동 분류표” 의 분당 칼로리 $(\mathrm{kcal} / \mathrm{min})$ 를 활용하여 운동종목 별 활동시간과 활동목표 등을 제공하였다. 또 한, 대상자들이 직접 보고 동작을 할 수 있도록 운동종목 을 동영상으로 제작하여 접근성을 쉽게 하였고, 운동전문
가가 대상자 개인별 신체활동 이력확인을 통하여 중간에 점증적으로 새로운 목표활동을 제공하였다. 목표심박수 는 안정시심박수를 활용한 예비심박수 공식을 활용하였 다(Karvonen \& Mustala, 1957).

\section{신체활동 지속도 확인}

신체활동 지속도는 특정 개인이 운동 혹은 신체활동에 직접 참가하여 그 활동을 정규적으로 행하는 것으로 조작 적 정의하였다. 미국스포츠의학회의 지침에 의하면 성인 들의 정규적인 운동참여는 가능하면 매일, 중증도 강도의 신체활동을 30 분 이상 하는 경우로 권고하고 있다(ACSM, 2006). 그러나 본 연구의 대상은 정상군이 아닌 건강위험 군이기 때문에 운동지속도는 최소 주 3 회, 30 분 이상으로 초기세팅을 하였고 개인마다 실행한 신체활동량은 스마 트 기반 모바일 헬스케어 앱에 자동 입력되어 모니터링 되도록 하였으며, Khealth(2016)에서 적용한 중도탈락 기 준에 의하여 2주 이상 활동데이터가 업데이트 되지 않으 면 신체활동 지속여부 의사가 없는 것으로 간주하여 자동 탈락으로 처리하였다.

\section{자료처리}

본 연구의 본 연구에서 측정된 자료는 SPSS 22.0 package(IBM, USA)를 이용하였다. 참여대상자의 신체활동 지 속도는 카이제곱을 이용하여 분석하였으며, 활동량계와 스마트 기반 앱 활용 유무에 따른 평균차이 검증과 상호 작용을 확인하기 위하여 이원 반복측정 분산분석(Twoway repeated measured ANOVA)을 실시하였고, 구체적인 시기 간 변화에 대한 효과를 알아보기 위하여 사후검증 (Scheffé)을 실시하였다. 모든 결과는 평균과 표준편차를 표시하였으며, 유의한 차이가 있는 모든 통계치의 검증을 위한 유의수준(significance level)은 $\alpha=.05$ 로 하였다.

\begin{tabular}{|cccc|}
\hline Table 2. The changes of physical activity adherence & \\
\hline \multirow{2}{*}{ Variables } & \multicolumn{2}{c|}{ Online Group } & \multirow{2}{*}{ Sig } \\
\cline { 2 - 3 } & Male & Female & \\
\hline drop-rate(\%) & 46 & 43 & \\
& $(9.35)$ & $(8.63)$ & $<.694$ \\
adherence(\%) & 446 & 455 & \\
\hline${ }^{*} p<.05,{ }^{* *} p<.01,{ }^{* * *} p<.001$ & & & \\
\hline
\end{tabular}




\begin{tabular}{|c|c|c|c|c|c|c|c|c|c|}
\hline \multirow{2}{*}{ Variable } & \multirow{2}{*}{ Group } & \multirow{2}{*}{ Base line } & \multirow{2}{*}{ Week 12} & \multirow{2}{*}{ Week 24} & \multicolumn{3}{|c|}{ F-value } & \multirow{2}{*}{ Significance } & \multirow{2}{*}{ Post-hoc } \\
\hline & & & & & $T$ & G & $T \times G$ & & \\
\hline $\mathrm{TC}(\mathrm{mg} / \mathrm{dL})$ & $\begin{array}{l}\text { G1 } \\
\text { G2 }\end{array}$ & $\begin{array}{l}190.00( \pm 37.75) \\
185.26( \pm 33.53)\end{array}$ & $\begin{array}{l}185.02( \pm 37.03) \\
181.24( \pm 39.45)\end{array}$ & $\begin{array}{l}187.55( \pm 35.56) \\
179.85( \pm 36.64)\end{array}$ & 7.591 & 4.802 & 2.233 & $\begin{array}{c}\text { T: } 001^{* * *} \\
\text { G: } 029^{*} \\
\text { T×G: } 206\end{array}$ & $\begin{array}{l}\mathrm{b}<\mathrm{a} \\
\mathrm{c}<\mathrm{a}\end{array}$ \\
\hline $\mathrm{TG}(\mathrm{mg} / \mathrm{dL})$ & $\begin{array}{l}\text { G1 } \\
\text { G2 }\end{array}$ & $\begin{array}{l}171.14( \pm 95.12) \\
175.52( \pm 102.01)\end{array}$ & $\begin{array}{c}168.53( \pm 101.73) \\
153.84( \pm 93.44)\end{array}$ & $\begin{array}{l}163.02( \pm 94.37) \\
161.91( \pm 86.05)\end{array}$ & 6.041 & 0.384 & 3.498 & $\begin{array}{c}\text { T: } 002^{* *} \\
\text { G: } 535 \\
\text { T×G: } 031^{*}\end{array}$ & $\begin{array}{l}\mathrm{b}<\mathrm{a} \\
\mathrm{c}<\mathrm{a}\end{array}$ \\
\hline $\begin{array}{l}\mathrm{HDL}-\mathrm{C} \\
(\mathrm{mg} / \mathrm{dL})\end{array}$ & $\begin{array}{l}\text { G1 } \\
\text { G2 }\end{array}$ & $\begin{array}{l}50.32( \pm 11.26) \\
50.67( \pm 10.33)\end{array}$ & $\begin{array}{l}51.15( \pm 11.66) \\
50.58( \pm 10.49)\end{array}$ & $\begin{array}{c}51.80( \pm 11.73) \\
50.49( \pm 9.32)\end{array}$ & 1.880 & 0.424 & 3.014 & $\begin{array}{c}\text { T: } 153 \\
\text { G: } 515 \\
\text { T×G: } 049^{*}\end{array}$ & - \\
\hline $\begin{array}{l}\mathrm{LDL}-\mathrm{C} \\
(\mathrm{mg} / \mathrm{dL})\end{array}$ & $\begin{array}{l}\text { G1 } \\
\text { G2 }\end{array}$ & $\begin{array}{l}100.78( \pm 36.53) \\
101.31( \pm 31.58)\end{array}$ & $\begin{array}{c}100.25( \pm 36.51) \\
99.26( \pm 32.32)\end{array}$ & $\begin{array}{l}103.31( \pm 34.01) \\
98.03( \pm 32.82)\end{array}$ & 4.193 & 2.264 & 1.835 & $\begin{array}{c}\text { T: } 015^{*} \\
\text { G: } 133 \\
T \times G: 160\end{array}$ & $\begin{array}{l}\mathrm{b}<\mathrm{a} \\
\mathrm{c}<\mathrm{a}\end{array}$ \\
\hline $\begin{array}{l}\text { Glucose } \\
(\mathrm{mg} / \mathrm{dL})\end{array}$ & $\begin{array}{l}\text { G1 } \\
\text { G2 }\end{array}$ & $\begin{array}{l}103.27( \pm 12.12) \\
103.65( \pm 14.16)\end{array}$ & $\begin{array}{l}106.57( \pm 16.44) \\
104.66( \pm 15.18)\end{array}$ & $\begin{array}{l}105.51( \pm 12.91) \\
105.97( \pm 15.92)\end{array}$ & 13.363 & 0.153 & 3.007 & $\begin{array}{c}\mathrm{T}: 000^{* * *} \\
\mathrm{G}: 695 \\
\mathrm{~T} \times \mathrm{G}: 050\end{array}$ & $\begin{array}{l}\mathrm{b}<\mathrm{a} \\
\mathrm{c}<\mathrm{a}\end{array}$ \\
\hline $\begin{array}{c}\text { SBP } \\
(\mathrm{mmHg})\end{array}$ & $\begin{array}{l}\text { G1 } \\
\text { G2 }\end{array}$ & $\begin{array}{l}128.35( \pm 14.69) \\
124.42( \pm 15.89)\end{array}$ & $\begin{array}{l}127.04( \pm 14.29) \\
125.00( \pm 14.51)\end{array}$ & $\begin{array}{l}125.82( \pm 13.57) \\
124.68( \pm 14.50)\end{array}$ & 3.093 & 5.984 & 4.347 & $\begin{array}{c}\text { T: } 046^{*} \\
\text { G: } 015^{*} \\
\text { T×G: } 013^{*}\end{array}$ & $c<a$ \\
\hline $\begin{array}{c}\text { DBP } \\
(\mathrm{mmHg})\end{array}$ & $\begin{array}{l}\text { G1 } \\
\text { G2 }\end{array}$ & $\begin{array}{l}83.00( \pm 10.34) \\
80.92( \pm 10.86)\end{array}$ & $\begin{array}{l}82.67( \pm 10.23) \\
80.25( \pm 10.12)\end{array}$ & $\begin{array}{c}82.15( \pm 10.12) \\
80.61( \pm 9.82)\end{array}$ & 1.510 & 8.580 & 0.985 & $\begin{array}{c}\text { T: } 221 \\
\text { G: } 003^{* *} \\
\text { TXG: } 374\end{array}$ & - \\
\hline $\begin{array}{l}\mathrm{G} 1 \text { : one-line } \\
\mathrm{T}: \text { Time, G: } \mathrm{G} \\
\mathrm{a}: \text { Baseline, b } \\
{ }^{*} \mathrm{p}<.05,{ }^{* *} \mathrm{p}<\end{array}$ & $\begin{array}{l}\text { hysical a } \\
\text { oup, T×G } \\
12 \text { Week } \\
01,{ }^{* * *} p\end{array}$ & $\begin{array}{l}\text { ity group, G2 : off-I } \\
\text { teraction } \\
24 \text { Week } \\
1\end{array}$ & ohysical activity g & & & & & & \\
\hline
\end{tabular}

\section{결 과}

\section{신체활동 지속도 변화}

<Table 2>에서 보는 바와 같이, 24 주 동안의 활동량계 와 스마트 기반 앱 이용에 따른 신체활동 지속도는 남자 가 492 명에서 446 명으로 46 명 $(9.35 \%)$ 의 탈락자를 제외 한 $90.65 \%$ 를 보였고, 여자는 498 명에서 455 명으로 43 명 (8.63\%)의 탈락자를 제외한 $91.37 \%$ 를 보였다. 남자와 여 자의 성별 간 카이제곱 결과에서 유의한 차이는 나타나 지 않았다.

\section{대사증후군 위험요인 변화}

<Table 3>에서 보는 바와 같이, 대사증후군 위험요인은 24 주 동안 활동량계와 스마트 기반 앱 이용에 따라 다양 한 결과를 보였다. 우선 총 콜레스테롤(TC)는 시간에 있 어서 유의한(F=7.591, $\mathrm{p}=0.001)$ 차이를 보였고, 그룹 간에 도 유의한(F=4.802, $\mathrm{p}=0.029)$ 차이가 나타났으나, 상호작
용에서는 차이 $(\mathrm{F}=2.233, \mathrm{p}=0.206)$ 가 나타나지 않았다. 그 리고 시기 간 변화에 대한 사후분석 결과는 12 주, 24 주 후 에 유의한 차이가 나타났고, 12 주에서 24 주 사이에는 유 의한 차이가 없었다. 수축기혈압(SBP)은 시간에 있어 유 의한 $(\mathrm{F}=3.093, \mathrm{p}=0.046)$ 차이가 나타났고 그룹 간에도 유 의한 $(\mathrm{F}=5.984, \mathrm{p}=0.015)$ 차이를 보였으며 상호작용 역시 유의한 $(\mathrm{F}=4.347, \mathrm{p}=0.013)$ 차이가 나타났다. 시기 간 변화 에 대한 사후분석 결과는 24 주 후에 만 유의한 차이가 나 타났다.

그리고 고밀도지단백 콜레스테롤(HDL-C)은 시간에 있 어 유의한(F=1.880, $\mathrm{p}=0.153)$ 차이가 없었고 그룹 간에도 유의한 $(\mathrm{F}=0.424, \mathrm{p}=0.515)$ 차이가 없었으나 상호작용에서 는 유의한(F=3.014, $\mathrm{p}=0.049)$ 차이가 나타났다. 중성지방 (TG)는 시간에 있어서 유의한(F=6.041, $\mathrm{p}=0.002)$ 차이를 보였고 그룹 간에는 유의한 $(\mathrm{F}=0.384, \mathrm{p}=0.535)$ 차이가 없 었으며 상호작용에서는 유의한(F=3.498, $\mathrm{p}=0.031)$ 차이가 나타났다. 시기 간 변화에 대한 사후분석 결과는 12 주, 24 


\begin{tabular}{|c|c|c|c|c|c|c|c|c|c|}
\hline \multirow{2}{*}{ Variable } & \multirow{2}{*}{ Group } & \multirow{2}{*}{ Base line } & \multirow{2}{*}{ Week 12} & \multirow{2}{*}{ Week 24} & \multicolumn{3}{|c|}{ F-value } & \multirow{2}{*}{ Significance } & \multirow{2}{*}{ Post-hoc } \\
\hline & & & & & $T$ & G & TXG & & \\
\hline BMI & $\begin{array}{l}\text { G1 } \\
\text { G2 }\end{array}$ & $\begin{array}{l}25.71( \pm 3.33) \\
25.20( \pm 3.47)\end{array}$ & $\begin{array}{l}25.66( \pm 3.26) \\
25.05( \pm 3.25)\end{array}$ & $\begin{array}{l}25.63( \pm 3.31) \\
25.02( \pm 3.42)\end{array}$ & 4.270 & 5.189 & 0.767 & $\begin{array}{c}\text { T: } 014^{*} \\
\text { G: } 023^{*} \\
\text { T×G: } 464\end{array}$ & $\begin{array}{l}\mathrm{b}<\mathrm{a}, \\
\mathrm{c}<\mathrm{a}\end{array}$ \\
\hline $\begin{array}{l}\text { Weight } \\
(\mathrm{kg})\end{array}$ & $\begin{array}{l}\text { G1 } \\
\text { G2 }\end{array}$ & $\begin{array}{l}70.86( \pm 12.82) \\
67.44( \pm 12.41)\end{array}$ & $\begin{array}{l}70.75( \pm 12.75) \\
67.25( \pm 12.17)\end{array}$ & $\begin{array}{l}70.63( \pm 12.82) \\
66.74( \pm 13.50)\end{array}$ & 5.854 & 13.606 & 1.815 & $\begin{array}{l}\text { T: } 003^{* *} \\
\text { G: } 000^{* * *} \\
\text { TxG: } 163\end{array}$ & $\begin{array}{l}c<a, \\
c<b\end{array}$ \\
\hline $\begin{array}{l}\text { Waist } \\
(\mathrm{cm})\end{array}$ & $\begin{array}{l}\text { G1 } \\
\text { G2 }\end{array}$ & $\begin{array}{l}88.29( \pm 9.35) \\
87.03( \pm 8.56)\end{array}$ & $\begin{array}{l}87.02( \pm 9.36) \\
85.62( \pm 8.15)\end{array}$ & $\begin{array}{l}86.33( \pm 9.17) \\
85.62( \pm 8.51)\end{array}$ & 45.277 & 2.732 & 3.017 & $\begin{array}{c}\text { T: } 000^{* * *} \\
\text { G: } 099 \\
\text { T×G: } 049^{*}\end{array}$ & $\begin{array}{l}\mathrm{b}<\mathrm{a}, \\
c<\mathrm{a}, \\
c<\mathrm{b}\end{array}$ \\
\hline $\begin{array}{l}\mathrm{G} 1 \text { : one-lin } \\
\mathrm{T}: \text { Time, G: } \\
\mathrm{a}: \text { Baseline, } \\
{ }^{*} \mathrm{p}<.05,{ }^{*} \mathrm{p}\end{array}$ & $\begin{array}{l}\text { hysical ac } \\
\text { oup, T×G } \\
12 \text { Week } \\
1,{ }^{* * *} p<\end{array}$ & $\begin{array}{l}\text { ty group, G2: off } \\
\text { eraction } \\
24 \text { Week } \\
1\end{array}$ & hysical activity & & & & & & \\
\hline
\end{tabular}

주 후에 유의한 차이가 나타났고, 12 주에서 24 주 사이에 는 유의한 차이가 없었다. 한편, 공복시 혈당(Glucose)은 시간에 있어서 유의한 $(\mathrm{F}=13.363, \mathrm{p}=0.000)$ 차이를 보였으 나, 그룹 간에 유의한 $(\mathrm{F}=0.153, \mathrm{p}=0.695)$ 차이를 보이지 않 았고 상호작용에서도 유의한 $(\mathrm{F}=3.007, \mathrm{p}=0.050)$ 차이가 없 었다. 시기 간 변화에 대한 사후분석 결과는 12 주, 24 주 후 에 유의한 차이가 나타났고, 12 주에서 24 주 사이에는 유 의한 차이가 없었다. 마지막으로 이완기혈압(DBP)과은 그룹 간에서만 유의한 $(\mathrm{F}=8.580, \mathrm{p}=0.003)$ 차이가 나타났 고, 저밀도지단백 콜레스테롤(LDL-C)은 시간에 있어서 유의한 $(\mathrm{F}=4.193, \mathrm{p}=0.015)$ 차이가 나타났으며 시기 간 변 화에 대한 사후분석 결과는 12 주, 24 주 후에 유의한 차이 가 나타났고, 12 주에서 24 주 사이에는 유의한 차이가 없 었다.

\section{신체조성의 변화}

표<Table $4>$ 에서 보는 바와 같이, 24 주 동안 활동량 계와 스마트 기반 앱 이용에 따라 나타난 결과는 다음 과 같다. 신체질량지수(BMI)는 시간에 있어서 유의한 $(\mathrm{F}=4.270, \mathrm{p}=0.014)$ 차이를 보였고, 그룹 간에도 유의한 $(\mathrm{F}=5.189, \mathrm{p}=0.023)$ 차이가 나타났으나, 상호작용에서는 차이 $(\mathrm{F}=0.767, \mathrm{p}=0.464)$ 가 나타나지 않았다. 그리고 시기 간 변화에 대한 사후분석 결과는 12 주, 24 주 후에 유의한 차이가 나타났고, 12 주에서 24 주 사이에 는 유의한 차이가 없었다. 체중(Weight) 역시 시간에 있어 유의한(F=5.854, $\mathrm{p}=0.003)$ 차이가 나타났고 그룹 간에도 차이를 보였으나,
상호작용에서는 유의한(F=1.815, $\mathrm{p}=0.163)$ 차이가 없었다. 그리고 시기 간 변화에 대한 사후분석 결과는 12 주, 24 주 후에 유의한 차이가 나타났고, 12 주에서 24 주 사이에는 유의한 차이가 없었다. 마지막으로 허리둘레(Waist)에서 는 시간에 있어서 유의한(F=45.277, $\mathrm{p}=0.000)$ 차이를 보였 으나 그룹 간에는 유의한 $(\mathrm{F}=2.732, \mathrm{p}=0.099)$ 차이가 없었 으며 상호작용에서는 유의한(F=3.017, $\mathrm{p}=0.049)$ 차이가 나 타났다. 그리고 시기 간 변화에 대한 사후분석 결과는 12 주, 24 주 후에 유의한 차이가 나타났고, 12 주에서 24 주 사 이에도 유의한 차이가 나타났다.

\section{논의}

본 연구의 목적은 시간과 공간의 제약이 없는 활동량 계와 스마트 기반 앱을 활용하여 신체활동 지속도와 대사 증후군 위험요인 및 신체조성에 어떠한 영향을 미치는지 를 확인하여 다음과 같이 논의하고자 한다.

\section{신체활동 지속도}

신체활동의 실천은 생활습관과 질병예방을 위한 차원 에서 시작하는 것이 필요하지만 같은 맥락에서 볼 때, 스 스로 자발성과 주도성을 가지고 지속적으로 신체활동에 참여할 수 있어야 하는 것도 중요한 항목일 것이다. 왜냐 하면 활동량계와 스마트 기반 앱 활용은 단기뿐만 아니 라, 장기간의 지속적 행동변화를 유도할 수 있어야 하며 생활습관의 변화과정이 개인마다 다르기 때문에 1 2회 
의 단발성보다는 반복적인 집중관리를 통하여 행동과 생 활습관의 변화를 가져오도록 해야 하기 때문이다(Verheijden et al, 2008).

2013년 9월 기준으로 활동량계를 보유하고 있는 미국 내 18 세 이상 성인을 대상으로 실시한 설문조사 결과에 따르면, 활동량계 사용 6 개월 이후 약 $30 \%$ 가 사용을 중단 하였고, 1 년 이상 사용하는 경우는 $50 \%$ 미만으로 나타났 다(Han, 2016). 따라서 활동량계와 스마트 기반 앱을 활용 하여 개인 신체활동 지속 여부를 확인하는 것은 참여자 의 생활습관 및 건강관리의 효과를 확인할 수 있는 중요 한 항목이라고 볼 수 있다(Kim et al, 2011). 본 연구에서 24 주 동안 규칙적인 신체활동 실천을 유지하기 위하여 활 동량계와 스마트 기반 앱 활용 후, 남자는 46명(9.35\%)의 탈락자를 제외한 $90.65 \%$ 의 지속도를 보였고, 여자는 43 명 (8.63\%)의 탈락자를 제외한 $91.37 \%$ 를 보였다. 즉, 남자와 여자 모두 매우 높은 신체활동 지속도를 나타내었고 중간 탈락률도 낮았다. 이는 Lee et al.(2015)이 보고한 스마트 기 반 앱 형태의 관리에서 연령층의 차이는 있지만 운동지속 도가 높게 나타난 결과와 일치하였으며 선행연구보다도 더 높은 지속도가 나타났다. 이처럼 남녀에 게서 $90 \%$ 이상 의 높은 지속도를 보인 것은 활동량계와 앱을 통해 개인 별 맞춤형 상담 및 일일 활동목표 제공, 그리고 걷기뿐만 아니라, 자신이 하고 싶은 운동을 수행하고 입력할 수 있 게 함으로써, 스스로 바람직한 신체활동 습관을 갖도록 유도한 방법이 효과적이었다고 생각된다.

또한 본 연구에서 언급하지는 않았지만, 영양학적 측 면에서 식사일기를 기록하게 하여 자신의 일일 섭취 칼 로리를 확인하게 한 부분도 영향을 미쳤을 것으로 생각 된다. 이 부분에 대해서는 후속 추적연구가 이루어져야 할 것이다.

한편 중간에 탈락한 대상자들은 활동량계의 “데이터 가 정확한가?” , “페어링이 잘 안된다.” , 그리고 앱 구 성도가 “한 눈에 안 들어온다.” 등의 다양한 이유를 제 기하였다. 즉 사용자 인터페이스(user interface; UI)의 난 이도와 데이터 검증 및 건강에 대한 관심을 증가시키는 맞춤형 콘텐츠가 부족한 점 등이 탈락의 원인으로 보여 진다. 따라서 추후에는 대상자들의 신체활동 참여를 지 속시키기 위해서 무분별한 프로그램 개발 이전에 대상자 에 맞는 화면구성과 재미, 그리고 개인 맞춤형 건강정보 제공을 위한 콘텐츠 개발에 대한 연구가 선행되어야 할 것이다.

\section{대사증후군 위험요인}

대사증후군 위험요인은 심혈관계 질환 발생 위험성 이 건강인과 비교하여 2 배 이상 높고 당뇨 발생 위험성은 3.5 5배 이상 높기 때문에, 예방을 위한 관리의 중요성이 부각되고 있고(Lee et al, 2015), 여러 관리방법 중에서 운동 이나 신체활동의 실천이 매우 밀접한 관계가 있으며 특 히, 운동 중에서 복합운동을 권장하고 있다(Ochner et al, 2007).

본 연구에서 규칙적인 신체활동을 동반한 활동량계와 스마트 기반 앱 이용이 총 콜레스테롤, 중성지방, 공복혈 당, 수축기혈압에서 긍정적인 결과가 나타났다. 이 결과 는 Oh et al.(2014)이 대사증후군을 가진 중년여성 23명에 게 10 주간 고정식 자전거운동과 저항운동으로 수축기혈 압에서 긍정적인 결과를 보인 것과 동일한 결과이다. 그 리고 $\operatorname{Kim}(2015)$ 이 규칙적인 걷기 참여가 비참여보다 중 성지방에서 유의하게 감소되었다고 보고한 결과와도 일 치하고, Kang \& Park(2012)이 고혈압, 당뇨, 이상지질혈증 등 대사관련 질환의 위험성이 규칙적인 신체활동으로 긍 정적인 효과를 보고한 결과와도 동일한 결과를 보였다. 이러한 사실은 운동이나 신체활동이 심장기능의 증가와 혈관기능의 개선 및 스트레스 감소로 혈압에 긍정적인 영 향을 미친것으로 보여진다(Kwon et al, 2012). 또한 Kwon et al.(2012)은 신체활동량의 증가가 대사증후군 위험요인과 발생 위험율을 낮추었다고 보고하였는데, 본 연구에서도 최초 주간 활동목표를 $60-70 \%$ 의 강도에서 실시해서 점증 적으로 활동목표를 증가시킨 것이 총 콜레스테롤, 중성 지방, 공복혈당, 수축기혈압에 긍정적으로 나타난 것이 라 생각된다.

한편, 사후검증 결과 고밀도지단백 콜레스테롤과 이 완기혈압을 제외한 대부분의 변인에서 12 주후, 24 주 후에 유의한 차이가 나타났으나, 12 주에서 24 주 사이에는 유의 한 차이가 나타나지 않았다. 그래서 추후 연구에서는 12 주 이후에 적극적인 참여 동기유발을 위한 전략적 방안 이 필요하다고 생각한다. 또한, 규칙적인 운동으로 고밀 도지단백 콜레스테롤이 유의하게 증가하였다는 선행연 구(Cho \& Kim, 2012)와 달리, 본 연구에서는 유의한 효과 가 나타나지 않았다. 이는 저항운동을 포함한 복합운동보 다는 유산소성 위주의 신체활동이 비율적으로 높았기 때 문으로 생각된다. 그러므로 향후에는 건강관리 활동 유 형과 형태 및 성별 간의 관찰을 통하여 대사증후군 위험 요인에 어떠한 변화가 있는지를 알아보는 연구가 진행되 
어야 할 것이다.

\section{신체조성}

본 연구에서 24 주 동안 규칙적인 신체활동과 활동량계 와 스마트 기반 앱을 활용했을 때, 허리둘레, 체중, 신체질 량지수에서 긍정적인 결과가 나타났다. 이러한 결과는 신 체활동 지속도가 높았기 때문에 오프라인에서 적극적인 운동이 체중과 허리둘레 감소에 긍정적인 영향을 미친 다 양한 선행 연구결과와 일치하였다(Sijie et al., 2012). 그리 고 규칙적인 유산소 운동이 체중을 감소시켰다는 연구결 과와도 일치하였다(Kim, 2015; Ko, 2011).

일반적으로 규칙적인 신체활동이 가져다주는 인체 변 화는 직접적인 운동에너지의 충족에 의해서 발생되기보 다는 기초대사량을 증가시켜 에너지 소비량의 증가가 나 타나기 때문인 데(Lazzer et al., 2011; Tompkins et al., 2011), 본 연구도 유산소성 운동과 적은 비율이지만 저항성 운동 으로 에너지 소비율을 자극시킴으로써 보다 긍정적인 신 체구성의 변화를 이끌어낸 것으로 생각된다. 또한, 사후 검증 결과 허리둘레에서는 12 주후, 24 주후, 그리고 12 주 와 24 주 사이에서 모두 유의한 차이를 보였으나, 신체질 량지수와 체중에서는 12 주와 24 주 사이에 유의한 차이가 없었기 때문에 대사증후군 위험요인과 같은 맥락에서 전 략이 필요하다. 그러므로 활동량계와 스마트 기반 앱을 통한 자발적인 운동량(유산소적 신체활동과 저항성 운 동)과 신체구성 변화에 대한 후속연구로 진행되어야 할 것으로 생각된다.

마지막으로 본 연구는 실험군과 대조군의 표본수 차이 가 크기 때문에, 연구결과의 표준화 부분을 평가하는데 제한점이 있다. 그러므로 향후에는 집단의 형평성을 포 함하고 나아가 서비스 종료시점(24주) 이후에 대상자의 건강상태와 신체활동 실천에 대한 추적관찰을 통하여 예 방적 차원의 건강관리 방안을 모색하는 정 책적 연구가 필 요하다.

\section{결론}

본 연구에서 수행된 활동량계와 스마트 기반 앱 적용 은 신체활동 지속도, 대사증후군 위험요인, 신체조성 변 인들에 긍정적인 효과가 있는 것으로 나타났다. 따라서 중장년층의 건강유지와 증진을 위한 매우 적합한 방법이 라고 볼 수 있다.
그러므로 지역 보건소에서는 주민들이 규칙적인 신체 활동에 참여하도록 유도하는 새로운 전략으로 활용할 수 있을 것으로 생각된다.

\section{Conflicts of Interest}

The authors declare no conflict of interest.

\section{References}

American College of Sports Medicine. (2006). Guidelines for exercise testing and prescription(7th ed.). Williams \& Wilkins.

Ainsworth, B. E., Haskell, W. L., Whitt, M. C., Irwin, M. L., Swartz, A. M., Strath, S. J., O'Brien, W. L., Bassett, D. R. Jr., Schmitz, K. H., Emplaincourt, P. O., Jacobs, D. R. Jr., \& Leon, A. S. (2000). Compendium of physical activities: an update of activity codes and MET intensities. Medicine and Science in Sports and Exercise, 32(9), 498-504.

Carron, A. V., Hausenblas, H. A. \& Estabrooks, P. A. (2003). The psychology of physical activity. McGraw-Hill Companies.

Cho, H. C. \& Kim, J. S. (2012). The effects of the complex exercise on body composition, activity fitness and cardiovascular disease risk factors in abdominal obese middle-aged women. Journal of Sport and Leisure Studies, 50(2), 957-967.

Gwon, O. S. \& Rhee, E. (2014). The relation of physical activity volume by lifecorder and fitness in primary school student -comparison with Japanese students. The Journal of Korean Society for Child Education, 23(2), 25-37.

Han, A. R. (2016). Effects of mobile healthcare application use and SMS/MMS as physical activity intervention on the levels of physical activity, (Master's thesis). Yonsei university, Seoul, Republic of Korea.

Health insurance review \& assessment service. (2016). Health Insurance Statistics Chronology 2015.

Jung, A. R., Song, S. J., Lim, S. Y., Lee, J. H., Choi, Y. H., \& Yoon, K. H. (2016). Study on preference of activity tracker of child and adolescent. Journal of Korea Society for Well- 
ness, 11(3), 471-483.

Jung, T. D., Lee, W., Choi, S., \& Min, W. K. (2013). Performance evaluation of the LABGEO PT10. Journal of Laboratory Medicine and Quality Assurance, 35, 70-80.

Kang, S. Y, \& Park, J. H. (2012). Study on physical activity level and blood lipid in intellectual disabled children. The Korean Journal of Physical Education, 51(1), 487-493.

Kannel W. B., D'Agostino, R. B., \& Cobb, J. L. (1996). Effect of weight on cardiovascular disease. The American Journal of Clinical Nutrition, 63(3 suppl), 419S-422S.

Karvonen, M., Kentala, K., \& Mustala, O. (1957). The effects of training in heart rate. Annales Medicine.

Kim, D. I. (2015). Relationships between walking, body mass index, and risk factors of metabolic syndrome among Korean adults: Data from the fifth Korea national health and nutrition Examination survey (2010-2012). Journal of Obesity and Metabolic Syndrome, 24(2), 108-115.

Kim, D. J., Kim, K. H., \& Lee, H. J. (2011). The effect of webbased self-health management program on adherence, body composition, flexibility and pulse efficiency index in high school students. Kinesiology, 13(2), 21-31.

Kim, D. J., Kim, I. K., Oh, Y. S., \& Shin, Y. J. (2010). Development of web-based personal exercise prescription system for health management. Kinesiology, 12(1), 73-82.

Kim, H. \& Lee, S. K. (2012). Effects of an individual health counseling program for community: Health one-stop service program. Korean journal of health education and promotion, 29(2), 13-21.

Kim, H. K. (2012). The Effects of smart phone application to Increase physical activity among university students, (Master's thesis), Seoul national university, Seoul, Republic of Korea.

Kim, S. H. (2015). Development and searching of physical activity continuity measurement scale(PACMS) for korean elderly women using Rasche rating scale model. Journal of Korean Physical Education Association for Girls and Women, 29(4), 265-280.

Korea Health Promotion Institute (2016). Result report to public health center mobile healthcare model development and demonstration.

Kwon, H. J. \& Sun, S. O. (2012). The effects of combined excer- cise program on health related fitness and risk factors related to metabolic syndrome in severely obese women. Journal of Korean Physical Education Association for Girls and Women, 26(2), 1-13.

Lazzer, S., Lafortuna, C., Busti, C., Galli, R., Agosti, F., \& Sartorio, A. (2011). Effects of lowand high-intensity exercise training on body composition and substrate metabolism in obese adolescents. Journal of Endocrinology Investigation, 34(1), 45-52.

Lee, G. A., Choi, H. Y., \& Yang, S. J. (2015). Effects of dietary and physical activity interventions on metabolic syndrome - A meta-analysis. Korean Society of Nursing Science, 45(4), 483-494.

Lee, W. K., Jung, C. K., Lee, B. K., \& Yoon, P. K. (2015). A plan of self-health management program on elementary school obesity students. The Korean Journal of Elementary Physical Education, 20(4), 161-171.

Ministry of Health and Welfare. (2013). People health statistics 2013.

Ministry of Science, ICT and Future Planning. (2017). Number current state of wireless communications service.

Myers, J., Gullestad, L., Bellin, D., Ross, H., Vagelos, R., \& Fowler, M. (2003). Physical activity patterns and exercise performance in cardiac transplant recipients. Journal of Cardiopulmonary Rehabilitation. 23(2), 100-106.

Ochner, C. N., Geliebter, A., Bauer, C. L., \& Hashim, S. A. (2007). Effects of strength and aerobic training on metabolic syndrome, insulin and testosterone levels in dieting obese subjects. Appetite, 49(1), 272-341.

Oh, S. I., Hwang, Y. S., \& Rhyu, M. J. (2014). Effcts of 10 Weeks combined exercise on metabolic syndrome related factor and inflammatory factors of obese women. Kinesiology, 16(3), 87-96.

OECD(2012). Health Care Quality Review: Korea, OECD 2012.

Orzano, A. J. \& Scott, J. G. (2004). Diagnosis and treatment of obesity in adults: an applied evidencebased review. The Journal of the American Board of Family Practice, 17(5), 359-69.

Sijie, T., Hainai, Y., Fengying, Y., \& Jianxiong, W. (2012). High intensity interval exercise training in overweight young 
women. The Journal of Sports Medicine \& Physical Fitness, 52(3): 255-62.

Thompson, W. R. (2014). Worldwide survey of fitness trends for 2015: What's driving the market. ACSM'S Health and Fitness Journal, 8(6), 8-17.

Verheijden, M. W., Jans, M. P., \& Hildebrandt, V. H. (2008). Web-based tailored lifestyle programs: exploration of the target group's interests and implications for prac- tice. Health Promotion Practice, 9(1), 82-92.

Vicki, S., Adam, R., \& David, R. (2011). Interventions to increase physical activity among healthy adults: meta-analysis of outcomes. American journal of public health. 101(4), 751-758.

WHO(2011). Noncommunicable Diseases - Country Profiles 2011. 